\title{
Adil Dünya İnancı ve Toplumsal Sonuçları
}

\author{
DOI: 10.26466/opus.610173
}

$*$

\section{Serap Akgün *}

* Doç. Dr, Mersin Üniversitesi, Sosyal Psikoloji ABD, Yenişehir / Mersin / Türkiye E-Posta: serapakgun@mersin.edu.tr

ORCID: $0000-0002-6733-6188$

\section{Öz}

Lerner'in Adil Dünya İnancı Kuramına göre (1975) insanlar herkesin genellikle hak ettiğini elde ettiği, iyilerin ödüllendirilip kötülerin cezalandırıldığı adil bir dünyada yaşadığına inanma ihtiyacındadır. Lerner adil dünya inancının bir yanılsama olduğunu, gerçekte dünyanın çok adil olmadığını ancak bu inancın kişinin kendini güvende hissetmesi için önemli olduğunu vurgulamıştır. Bu inanç bireylerin sosyal ve fiziksel çevrelerini adil, yordanabilir ve konrol edilebilir görmelerini kolaylaştırır. Böylece geleceğe güvenle bakabilir ve uzun vadeli amaçlarına ulaşmak için çabalayabilirler. Kurama göre masum kurbanlar insanların adil dünya inancinı tehdit eder. Bu tehditle baş edebilmek ve bu inancı koruyabilmek için kurbana yardım etme gibi akılcı yolların yanı sıra kurbanı suçlama ya da değersizleştirme gibi bilişsel çarpıtmalar da kullanılabilmektedir. Kurbanı suçlamanın toplumsal sonuçlar son derece ciddi görünmektedir. Bu derleme çalışmasında Lerner tarafindan geliştirilen Adil Dünya İnancı Kuramının temel önermeleri ve bu önermeleri test eden görgül araştırma bulguları sunulmuştur. Adil dünya inancını korumak uğruna kurbanı suçlamanın ya da değersizleştirmenin toplumsal sonuçları tartışılmıştır.

Anahtar Kelimeler: Adil dünya inancı, yardım, kurbanı suçlama 


\title{
Belief in a Just World and Its Social Consequences
}

$*$

\begin{abstract}
According to the belief in a just world theory, developed by Lerner (1975), people need to believe that they live in a just world where everyone lives what they deserve, good persons are rewarded while bad persons are punished. Lerner stated that belief in a just world is an illusion infact the world is not always fair, however, just world belief plays an important role in feeling secure. This belief leads to individuals to perceive their social and physical environment as fair, predictable, and controllable. Thus they look to the future with confidence and they can strive to reach their long-term goals. According to the theory, innocent victims threaten people's belief in a just world, to cope with this threat and to maintain their beliefs people use cognitive distortions such as blaming or derogating the victim alongside the rational strategies such as helping to the victim. Blaming the innocent victims has severe consequences not only for victims but also for the whole society. In this review main propositions of Lerner's belief in a just world theory and the results of the empirical studies testing these propositions were presented. Then the social consequences of blaming or derogating innocent victims in order to protect the just world belief were discussed.
\end{abstract}

Keywords: Belief in a just world, helping behavior, victim blaming 


\section{Giriş}

Adalet insanlığın zihnini meşgul eden en temel kavramlardan biridir. İnsanlar yaşadıkları, tanık oldukları ya da yalnızca duydukları pek çok olayın ne derece adil olduğu konusunda düşünür, kararlar verir, yarg1larda bulunurlar. Bu derleme çalışmasında insanların dünyanın adil olduğuna dair bir yanılsama yaşadıklarını vurgulayan Adil Dünya İnancı Kuramı tanıtılmış, bu kuramı sınamak amacı ile yapılan görgül araştırmalar anlatılmış ve adil dünya inancının toplumsal sonuçları tartışılmıştir.

Lerner'in (1980) adil dünya inancı kuramına göre insanlar dünyanın herkesin genellikle hak ettiğini yaşadığı, iyilerin ödüllendirilip kötülerin cezalandırıldığı, adil bir yer olduğuna inanmaya güdülenmişlerdir. İnsanlar kaderlerinin ve şanslarının kendi davranışlarına ve karakterlerine bağlı olduğuna inanmak isterler. Dünyanın adil olduğuna inanmak temel bir yanılsamadır. Yanılsamadır, çünkü aslında yanlıştır ama güdüsel olarak savunulur. Yaşam adil değildir, insanlar hemen her gün pek çok adaletsizliğin tanığı ya da kurbanı olurlar ama yine de dünyanın adil bir yer olduğuna inanmak isterler. Adil dünya inancı, dünyanın düzenli ve kararlı bir yer olduğunu düşünmeye yol açar. İnsanlar içinde yaşadıkları bu adil dünyada hak ettikleri şeylere sahip olacaklarına, öngörülemeyen olayların kurbanı olmayacaklarına inanırlar. Böylece geleceğe güvenle bakabilir ve uzun vadeli planlarını hayata geçirmek için çabalayabilirler. $\mathrm{Bu}$ inanç sayesinde dünyayı güvenli bir yer olarak algılayabilir ve ruh sağlıklarını koruyabilirler (Lerner, 1980; 1998). Dünyanın adil olduğu inancı bireyler için böyle önemli bir uyum sağlama işlevine hizmet ettiğinden dolayı insanlar bu inancı terk etme konusunda oldukça dirençlidir. İnsanlar dünyanın gerçekte adil ve düzenli olmadığını gösteren kanıtlarla karşılaşırlarsa büyük sıkıntı yaşayabilirler (Lerner ve Miller, 1978, s.1030).

Lerner Adil Dünya İnancı Kuramını test etmek için yaptığı ilk deneysel çalışmalardan birinde (1965) üniversite öğrencilerinden bir deneye katılan ve birlikte anagram çözme (kelime türetme) görevi verilen iki kişiyi değerlendirmelerini istemiştir. Aslında gerçek katılımcılar deneyi gözlediklerini sanan üniversite öğrencileridir. Öğrencilere araştırma bütçesinin kısıtlı olduğu bu nedenle katılımcıların ikisine birden para ödülü 
verilemeyeceği bunun yerine deneyin sonunda ödülün kura ile bu iki kişiden birine verileceği söylenmiştir. Katılımcıların performanslarından bağımsız olarak kura ile birinin ödüllendirileceği bilgisi deneyin ortalarında tekrar hatırlatılmıştır. Deneyin sonunda birlikte çalışan ve kura ile yalnızca birinin ödüllendirildiği diğerinin ise hiçbir şey alamadığı oturumu izleyen üniversite öğrencilerinden bu iki kişiyi değerlendirmeleri istendiğinde para alanın para almayandan daha üretken olarak değerlendirildiği görülmüştür. Para dağıtıldıktan sonra katılımcılar biri iyi kaderini diğeri ise kötü kaderini hak eden iki kişi gördüklerini düşünmüşlerdir. Lerner insanların, aktörün tamamen şans eseri ödüllendirildiğini bildikleri durumlarda bile olayları anlamlandırırken gözlediklerini değil olayın sonucunu dikkate aldıklarını vurgulamıştır.

Dünyanın adil olduğu inancı, iyi ya da kötü ne yaşanırsa yaşansın bunun hak edildiği düşüncesine yol açmaktadır. Ödül genellikle iyiliğin bir işareti olarak görülür. Gazeteler şans oyunlarında kazananların çok çalışmak, iyi davranmak gibi hayran olunacak niteliklerinden söz ederler, sanki bu özellikleri şanslı bileti almalarının nedeni imiş gibi (Rubin ve Peplau, 1975). Lise ve üniversite sinavlarında yoksulluk ve imkansızlıklara rağmen başarılı olmuş öğrenciler yeterince çalışılırsa her zorluğun üstesinden gelinebileceğinin yani dünyanın adil olduğunun kanitı olarak sunulurlar. Oysa olanaksızlıklardan dolayı başaramamış binlerce öğrencinin yaşadığı adaletsizlik dikkat çekmez çünkü bu durum dünyanın adil olduğu inancı ile uyuşmaz. Heider (1958, akt. Rubin ve Peplau, 1975) adil dünya inancının daha genel bir bilişsel denge ilkesinden kaynaklanan yaygın bir bilişsel yanlılık olduğunu belirtmiştir. İyilik ve mutluluk, kötülük ve ceza arasındaki ilişki güçlüdür. Bunlar birlikte bulunuyorsa durumun olması gerektiği gibi olduğunu, yani adaletin hüküm sürdüğünü düşünürüz. Öte yandan kötülük ve mutluluğun birlikteliği uyumsuzdur. İyilik ve mutsuzluk, kötülük ve mutluluk birlikte ise bilişsel çelişki yaşanır. Bilişsel çelişkiler insanı rahatsız eder ve bu çelişkiyi gidermeye güdüler.

Günlük yaşamda sıklıkla kullanılan atasözü ve deyimler dünyanın adil olduğunu vurgulamaktadır (Dik, 2010). "Ne ekersen onu biçersin", "alma mazlumun ahını çıkar aheste aheste", "etme bulma dünyası" gibi atasözleri bizim kültürümüzden birkaç örnektir. Pek çok din iyiliğin ödüllendirildiği kötülüğün cezalandırıldığı bir dünyada yaşadığımızı 
söyler, bu dünyada olmasa bile öteki dünyada adalet vaat eder (Lerner, 1980, 1998; Rubin ve Peplau, 1975). Masallar, mitolojik hikayeler, filmler dünyanın adil bir yer olduğu mesajını verirler. Lerner (1980) bütün yaz çalışıp kış için yiyecek biriktiren ve kışın rahat eden karınca ile bütün yaz saz çalıp eğlenen ve kışın aç kalan ağustos böceğinin hikayesine atıfta bulunarak, çocukların bu hikayelerden yoksul insanların ağustos böceği gibi oldukları çıkarımını yaptıklarını belirtmiştir. Neredeyse tüm masallarda iyi kalpli kahramanlar ödüllendirilirken kötüler cezalarını çekerler. Pamuk prenses prensle evlenerek sonsuza dek mutlu yaşarken, kötü cadı ölür. İyi kalpli keloğlan prensesle evlenir ve yoksulluktan kurtulur. Masallar "onlar ermiş muradına" diye biter. Dünyanın adil olduğu mesajları ile büyüyen çocuklar bir süre sonra adil dünya inancına sahip olmaya başlarlar.

Adil dünya inancının hangi yaşlarda geliştiğini saptamak amacı ile ana sınıfından üniversiteye kadar pek çok yaş grubundan katılımcı ile yapılan bir çalışmada (Jose, D'Anna ve Krieg, 2005) katılımcilara Ezop masalları (fabllar) okunmuştur. Bir koşulda adaletin tecelli ettiği Ezop masalları olduğu gibi okunurken diğer koşulda masalların sonunun tersine çevrilmiş halleri okunmuştur. Katılımcılara masalları ne kadar sevdikleri sorulmuştur. Anasınıfı, birinci sınıf ve ikinci sınıf öğrencilerinin bu iki farklı son ile biten öyküler arasında bir ayrım yapmadıkları yani iki tür sonu da eşit derecede sevdikleri gözlenirken ilkokul dördüncü, beşinci, sekizinci sınıf öğrencilerinin ve üniversite öğrencilerinin adaletin işlediği orijinal masalları adil olmayanlardan daha çok sevdikleri gözlenmiştir.

Benzer bir başka çalışmada Jose ve Brewer (1984) ikinci, dördüncü ve altıncı sınıfa giden ilkokul çocuklarına kahramanı iyi ya da kötü olan ve sonunda kahramanın başına iyi ya da kötü bir olayın geldiği öyküler okutarak bu öyküleri ne kadar sevdiklerini sormuşlardır. İkinci sınıfa giden çocuklar (7 yaş) kahramanın başına iyi şeylerin geldiği öyküleri kötü şeylerin geldiği öykülerden daha çok sevmişlerdir. Dördüncü sınıfa giden çocuklar (9 yaş) iyi karakterin başına iyi şeylerin geldiği öyküleri en çok, kötü karakterin başına iyi ya da kötü şeylerin geldiği öyküleri orta derecede, iyi karakterin başına kötü şeylerin geldiği öyküleri ise en az sevmişlerdir. Altıncı sınıfa giden çocuklar (11 yaş) ise adil dünya inancına uygun olarak, iyi kahramanın başına iyi şeylerin kötü kahra- 
manın başına ise kötü şeylerin geldiği öyküleri diğerlerinden daha çok sevdiklerini belirtmişlerdir.

Brewer (1996) yetişkinlerde adil dünya inancını incelemek için iki farklı sonla biten iki ayrı senaryo kullanmıştır. Katılımcılardan atandıkları koşula bağlı olarak bu dört senaryodan biri verilmiş ve okumaları istenmiştir. Öykülerden birinde Cebeli Tarık boğazını yüzerek geçmek için yıllardır çalışan ve iki çocuğuna bakabilmek için bu başarının sonucunda kazanacağı para ödülüne ihtiyacı olan bir kadın yüzücü anlatılmıştır. Katılımcların bir bölümü bu yüzücünün dalgalara ve denizanalarına rağmen boğazı geçtiği öyküyü, diğer bölümü ise aşırı dalga ve denizanaları yüzünden çok uğraşmasına rağmen geçemediği öyküyü okumuştur. İkinci öyküde ise hapisten kaçıp yaşlı bir kadının evinde saklanan iki mahkum yaşlı kadına saldırmıştır. Öykülerden birinde yaşlı kadın kendini savunup mahkumları merdivenden aşağı yuvarlamış, diğerinde ise mahkumlar yaşlı kadını öldürmüşlerdir. Öyküleri okuduktan sonra katılımcılara öykünün sonundan ne derece memnun kaldıkları ve öykünün ne derece tamamlanmış olduğu sorulmuştur. Katılımcılar adaletin tecelli etmediği öykülerden hoşlanmamışlardır. Adil olmayan sonlarla biten öyküler yalnızca sevilmemekle kalmamış ayrıca yarım kalmış, tamamlanmamış gibi algılanmıştır.

Bazen iyi insanların başına kötü şeyler geldiğine tanık olur, adaletsizliğin kanıtları ile karşılaşırız. Böyle zamanlarda adil dünya inancımız sarsılır. Adil Dünya İnancı Kuramı masum kurbanların adil dünya inancımızı tehdit ettiğini söyler. Hafer (2000) görgül olarak test edilmesi zor olan bu hipotezi deneysel bir çalışma ile test etmiş ve desteklemiştir. Araştırmada katılımcılara, seyahat ettiği sırada saldırıya uğrayan 19 yaşındaki bir gencin haberi izletilmiştir. Bir koşulda saldıranların yakalanıp hapse atıldığ1 diğer koşulda ise saldırganların ülkeden kaçtığ1 ve cezalandırılamadığı vurgulanmıştır. Ardından katılımcılara bir Stroop görevi verilmiştir. Bu görevde katılımcılardan ekrana kısa bir süre için yansıtılan her bir kelimenin hangi renk ile yazılmış olduğunu önlerindeki renkli düğmelere basarak belirtmeleri ve olabildiğince hızlı tepki vermeleri istenmiştir. Stroop görevinde kelimenin anlamı ve renk uyumsuz olduğunda renk tanımada gecikme gözlenir. Örneğin, yeşil renk ile "kırmızı" kelimesi yazıyor ise yeşil düğmeye basma süresi uzar. Benzer olarak, sağlı̆̆1 konusunda endişeli kişiler "masa", "kaşık" gibi nötr keli- 
melerden ziyade "kanser" gibi kelimelerde daha uzun sürede renk teşhisi yapabileceklerdir çünkü "kanser" kelimesinin kişi için anlamı onun bilişlerini aktive edecek, dikkatinin bu yöne kaymasına yol açacak ve renk tanıma görevinde tepki süresini uzatacaktır. Hafer, saldırganların ülke dışına kaçtığı koşulda katılımcıların adil dünya inançlarının daha çok tehdit edildiğini dolayısıyla bu koşuldaki katılımcıların Stroop görevinde "adil", eşitsizlik" gibi adalet ile ilgili kelimelere "sınıflanmış", "geniş" gibi nötr kelimelere kıyasla daha geç tepki verildiğini bulmuştur. Suçluların cezalandırıldığı yani adil dünya inancının tehdit edilmediği ya da daha az tehdit edildiği koşulda ise adaletle ilgili kelimeler ile nötr kelimelerin renklerini teşhis etme süresi arasında anlamlı bir fark bulunmamıştır. Hafer adil dünya inancı tehdit edilen katılımcıların zihinlerinin adaletle meşgul olduğunu bu nedenle adaletle ilgili kelimelere nötr kelimelerden daha yavaş tepki verdiklerini vurgulamıştır. Bulgular, adaletin tecelli etmediği durumlarla karşılaştığımızda adil dünya inancımızın tehdit edildiğini desteklemiştir.

Adil dünya inançları tehdit edilen insanlar bu inançlarını korumak için bazı yollar kullanırlar. Lerner (1980) bu yolları rasyonel stratejiler ve irrasyonel (ya da savunmaci) stratejiler olmak üzere iki kategori altında toplamıştır. Rasyonel stratejiler ortada bir adaletsizlik olduğunu kabul etmeyi ve ardından bunu azaltmayı ya da adaleti yeniden yapılandırmayı içeren yollardır. Kurbana yardım etmek, zararı tazmin etmeye çalışmak gibi adaleti yeniden sağlamaya ya da adaletsizliğin şiddetini azaltmaya yönelik yollar rasyonel yollar olarak adlandırılır. İşsizlik maaşı, sağlık sigortası, kimsesiz çocukların bakımı ve sivil toplum kuruluşlarının yardımları kurumsal olarak bu işlevi görmektedir. İnsanlar bireysel olarak da kurbanlara yardım etmeye, zararı azaltmaya çalışabilirler. İrrasyonel stratejiler ise bir adaletsizliğin olduğunu görmezden gelmeyi ya da reddetmeyi ve adaletsiz olayı yeniden yorumlamayı içerir. Kişi olayın nedenini, kurbanın karakterini ya da olayın sonucunu yeniden yorumlayarak psikolojik olarak adaleti sağlamaya çalışabilir. Nedeni yeniden yorumlayan kişi kurbanın yaşadıklarının nedeninin kurbanın yaptığı yanlışlar olduğunu dolayısıyla yaşadığını hak ettiğini düşünür. Tacize uğramış birisi için "şort giymeseydi" ya da "gece dışarıda ne işi varmış" gibi söylemler, nedeni yeniden yorumlayarak kurbanı suçlamanın örnekleri olarak verilebilir. Kurbanın karakterini yeniden yorumlayan kişi 
kurbanın iyi şeyler hak edecek niteliklere ya da kişisel özelliklere sahip olmadığını değersiz ya da kötü bir insan olduğunu düşünür. Adaletsiz olayın sonucunu yeniden yorumlayan kişi ise aslında bu sonucun olumsuz değil olumlu olduğuna, çektiği acıların kurbanı olgunlaştırdığına, güçlendirdiğine inanabilir.

Lerner $(1980,1998)$ adil dünya inancını korumak için başka yollar da kullanıldığını belirtmektedir. Dünyanın adil olduğu inancını korumanın en kolay ve en etkili yolu bu inancin test edilmesine asla izin vermemektir. Bu nedenle yetişkinler çocuklardan farklı olarak iyiliğin anında ödüllendirileceğine kötülügün anında cezalandırılacağına (immanent justice) değil, gelecekte yaşanacak olayların bugün yaşanan adaletsizlikleri ortadan kaldıracağına yani nihai adalete (ultimate justice) inanırlar. Bu inançta adaletin ne zaman yerini bulacağı keyfi bir zamanla sınırlı değildir. İnsanlar adaletin hemen olmasa bile eninde sonunda geleceğine inanırlar. Adil dünya inancını korumanın bir diğer yolu kişinin kendi dünyasını "kurbanların dünyasından" ayrıştırmasıdır. İnsanlar dünyada açlık, afetler, savaşlar gibi kurbanların acı çektiği pek çok adaletsizliğin olduğunu reddedemezler ancak adil dünya inançlarını korumak için bu adaletsizliklerin başka bir dünyada olduğuna inanırlar. İnsanlar çevrelerinde en az iki ayrı dünya olduğunu düşünürler. Bunlardan biri haksızlıkların olduğu dünya diğeri ise kendi adil dünyalarıdır.

\section{Adil Dünya İnancı ve Kurbana Yardım Etme}

Lerner (1980) masum kurbanların insanların adil dünya inançlarını tehdit ettiğini bu nedenle yardımın mümkün olduğu ve yardımın bedelinin yüksek olmadığı durumlarda insanların kurbana yardım ederek, yard1mın mümkün olmadığı ya da bedelinin yüksek olduğu durumlarda ise kurbanı suçlayarak ya da değersizleştirerek adil dünya inançlarını korumaya çalıştıklarını belirtmiştir. İlk deneysel çalışmalarından birinde Lerner ve Simon (1966) kurbana yardım etmenin mümkün olduğu ve olmadığı durumlarda insanların ne tür tepkiler verdiklerini araştırmıştır. Çalışmada üniversite öğrencileri stresli durumlarda performansın nasıl etkilendiğinin araştırıldığı bir deneyi seyrettiklerine inandırılmışlardır. Oysa gerçekte kendileri araştırmanın katılımcılarıdır. Öğrencilerden, deney esnasında yanlış yanıtlar verdiğinde elektrik şoku alan bir sahte 
katılımcının görüntülerini seyretmeleri (gerçekte böyle bir şok verilmemiştir) ve sahte katılımcının duygusal durumuna ilişkin ipuçlarına dikkat etmeleri istenmiştir. Ardından, bir koşulda öğrencilere deneyin bir sonraki aşamasında kurbanı (sahte katılımcıyı) elektrik şoku koşulu yerine doğrularının para ile ödüllendirildiği ödül koşuluna atama fırsatı verilmiştir. Bu koşuldaki öğrencilerin hepsi kurbanı ödül koşuluna atayarak uğradığı zararı tazmin etmeye çalışmışlardır. Böylece katılımcılar durumu adaletli bir biçimde yeniden yapılandırabilmiş̧lerdir. Bir diğer koşulda ise katılımcılara kurbanı ödüllendirme fırsatı verilmemiş ve deneyin bir sonraki aşamasında da şokun devam edeceği söylenmiştir. Tüm öğrencilerden kurbanı "sempatik", "olgun" gibi bir dizi kişisel özellik açısından değerlendirmeleri istenmiştir. Kurbanın gördüğü zararı tazmin etme şansı olmayan katılımcıların kurbanı ödüllendirme seçeneği verilen gruba kıyasla kurbanı daha olumsuz değerlendirdikleri bulunmuştur. Araştırmacılar, kurbana yardım ederek adaleti sağlama şansı olmayan kişilerin kurbanı değersizleştirerek adaleti sağlamaya çalıştıklarını belirtmişlerdir.

Lerner ve Simon'un (1966) yukarıda anlatılan deneyinde katılımcıların çoğu deneyi ilginç ve eğlenceli bulduğunu belirtirken bir bölümü zalimce bulduklarını belirtmişlerdir. Bu iki grubun kurbanı değerlendirmeleri arasında da anlamlı farklar bulunmuştur. Deneyi acımasız bulanlar kurbanı daha pozitif değerlendirmişlerdir. Yani deneyi ve kurbanı değerlendirme arasında bireysel farklar gözlenmiştir. Bu çalışmanın bulgularından yola çıkan Rubin ve Peplau (1973) bireyler arasında adil dünya inancı açısından farklar olduğunu, bazı insanların dünyanın adil olduğu inancını devam ettirebilmek için "kurbanı değersizleştirmek" gibi bilişsel çarpıtmalar yaptıklarını ancak diğer bazı insanların da dünyanın genellikle adil olmadığının farkında olduklarını belirtmişlerdir. Güçlü bir adil dünya inancına sahip olanlar, iyi bir kadere sahip olanları kötü bir kadere sahip olanlardan daha çok şeyi hak eden ve daha çok hayran olunacak insanlar olarak değerlendirme eğilimindedirler. Öte yandan dünyanın keyfi bir yer olduğuna, çok da adil olmadığına inananlar böyle bilişsel çarpıtmalara başvurmazlar. Hatta tam tersine değerlendirmeler yaparlar; kötü kadere sahip olanları reddetmek yerine onlara sempati duyarlar, iyi kadere sahip olanlara hayran olmak yerine onlara gücenirler. Yazarlar bu inanç açısından bireysel farklılıkları değerlendi- 
rebilmek için Adil Dünya Ölçeği'ni (Just World Scale) geliştirmişlerdir. Rubin ve Peplau'nun adil dünya inancı açısından bireysel farklara vurgu yapmaları ve bu inancı değerlendirmek için bir ölçme aracı geliştirmeleri, araştırmacıların rasyonel ve savunmacı stratejileri kullanma açısından adil dünya inancı yüksek ve düşük bireylerin farklılaşıp farklılaşmadığ 1 konusuna odaklanmasına yol açmıştır. Bu çalışmalarda temel varsayım, güçlü bir adil dünya inancına sahip kişilerin masum kurbanlarla karşılaştıklarında adil dünya inançlarının daha çok tehdit edileceği, bu nedenle zayıf bir adil dünya inancına sahip olanlara kıyasla yardım etmek gibi rasyonel stratejileri de kurbanı suçlamak gibi irrasyonel stratejileri de daha çok kullanacağıdır.

Kurbana yardım etmeyi inceleyen bir çalışmada (Bierhoff, Klein ve Kramp, 1991) bir trafik kazası senaryosu hazırlanmış ve kazaya tanık olup kurbanlara yardım edenler ile etmeyenlerin bireysel özellikleri karşılaştırılmıştır. Kazaya tanık olan kişilerden yardım edenlerin adil dünya inancının yardım etmeyenlerden daha yüksek olduğu bulunmuştur. Kuramla uyumlu olarak yüksek adil dünya inancına sahip bireyler kazada kendi sorumlulukları olmayan kurbanlara daha çok yardım etmişlerdir. Zuckerman (1975) da adil dünya inancı yüksek ve düşük olan üniversite öğrencilerinin görmeyen bir öğrenciye kitap okuyarak yardım etmeye gönüllülükleri arasında bir fark olup olmadığını test etmiştir. Adil dünya inancı daha yüksek olan öğrenciler bu inancı düşük olan öğrencilere kıyasla görmeyen bir öğrenciye kitap okumak için daha çok zaman ayırabileceklerini belirtmişlerdir.

Ancak adil dünya inancı ve yardım etme arasındaki ilişkiyi inceleyen araştırma bulguları hep aynı yönde değildir. Örneğin, Zuckerman'ın (1975) aynı makalede yer alan bir diğer çalışmasında, üniversite öğrencilerinin adil dünya inançları değerlendirildikten sonra ara sinavlardan beş hafta önce ve ara sinavlardan iki gün önce öğrencilere telefon açılmış ve bir deneye katılarak bir yüksek lisans öğrencisine yardımcı olup olamayacakları sorulmuştur. Bulgular, ara sınavlardan beş hafta önce adil dünya inancı yüksek ve düşük öğrencilerin yardım etme oranları arasında bir fark olmadığını ancak ara sınavlardan iki gün önce aynı yardım talep edildiğinde adil dünya inancı yüksek olanların düşük olanlardan daha çok yardım etme eğiliminde olduklarını göstermiştir. Zuckerman adil dünya inancı yüksek olanların her zaman değil ama iyi talihe ihti- 
yaçları olduğunda (sınav öncesi) yardım edip sonra bu yardımın ödülünü beklediklerini vurgulamıştır.

Adil dünya inancının göçmenlere, işsizlere ve üçüncü dünya ülkelerindeki fakir insanlara yardım etme ile ilişkisini inceleyen bir çalışmada (Reichle, Schneider ve Montada, 1998) katılımcıların adil dünya inancı arttıkça sosyal adaletsizliğin kurbanlarına yardım etmek için maddi katkıda bulunma, imza kampanyasına imza atma ya da kolektif eylemlere katılma isteklerinin düştüğü görülmüştür. Bir başka deyişle, yüksek adil dünya inancı daha çok yardım etme ile değil daha az yardım etmeyle ilişkili bulunmuştur. Türkiye'de yapılan bir araştırmada da (Yıldırım ve Akgün, 2013) dezavantajlı gruplara yardım etmek için en az bir yıldır bir sivil toplum kuruluşunda gönüllü olarak çalışan kişilerin genel adil dünya inançlarının böyle bir sivil toplum kuruluşunda hiç çalışmamış olanlardan daha düşük olduğu bulunmuştur. Bu bulgu yardımın emek ve zaman gerektirdiği durumlarda adil dünya inancı yüksek olanların değil düşük olanların daha çok yardım ettiğine işaret etmektedir. Adil dünya inancı ve kurbana yardım etme ilişkisini inceleyen az sayıda çalışma bulunmaktadır. Bu çalışmaların bulguları da güçlü bir adil dünya inancına sahip olanların masum kurbanlara daha çok yardım edecekleri beklentisini desteklemekten çok uzak görünmektedir. Bunun nedeni adil dünya inancını korumanın kurbanı suçlama gibi bedeli daha düşük yollarının da olması olabilir.

Kurbanın yaşadığı talihsiz olaylardan sorumlu algılanması ve suçlanması kurbana yardım etmemeye yol açabilir. Weiner (2012) sorumluluk yükleme kuramında metaforlardan yararlanarak hayatı mahkeme salonuna insanları da hakimlere benzetmektedir. İnsanlar başına talihsiz olaylar gelmiş kişileri tıpkı bir hakim gibi yargılayarak içinde bulunduğu durumdan kişisel olarak sorumlu olup olmadıklarına karar verirler. Kurbanın içinde bulunduğu zor durumdan sorumlu olmadığını düşündüklerinde ona karşı sempati ya da merhamet hissetmekte ve yardım etmeye çalışmaktadırlar. Öte yandan, kişinin yaşadığı şanssız olaydan sorumlu olduğunu düşündüklerinde kişiyi suçlamakta, ona karşı öfke hissetmekte ve yardım etmemeyi tercih etmektedirler. 


\section{Adil Dünya İnancı ve Kurbanı Suçlama}

Daha önce söz edildiği gibi kurbana yardım ederek zararı tazmin etmeye çalışmak adil dünya inancını korumanın tek yolu değildir. Bazen insanlar kurbanı suçlayarak, değersizleştirerek, çektiği acıları hak ettiğini düşünerek de adil dünya inançlarını korumaya çalışabilirler. Böylece kendilerini daha az incinebilir hissederler ve yaşamda daha az riskleri olduğu algısına sahip olurlar. Çünkü olumsuz sonuçları hak edecek bir şey yapmadıklarına inanırlar. Pek çok insan talihsiz olaylar yaşayan birini gördüğünde ya kurbanın abarttığı, çok da acı çekmediği ya da kurbanın suçlu olduğu, kötü kaderini hak ettiği sonucuna varır.

İnsanların kurbanın acılarını reddettiğini ya da kurbanı aşağıladığını gösteren görgül veriler de bulunmaktadır. Örneğin, Hallie (1971, akt. Rubin ve Peplau, 1975) Nazi rejimini yaşayan pek çok Alman'ın kitle katliamlarını ya reddettiklerini ya da ölüm kamplarına yollananların saf ırk olmadıkları için bunu hak ettiklerini düşündüklerini kaydetmiştir. Amerika'da bu dönemde yapilan anketler Nazi zulmünün Yahudilere sempati duyulmasının ötesinde Yahudi karşıtlığını artırdığını göstermiştir (Selznick ve Steinberg, 1969, akt. Rubin ve Peplau, 1975).

Almanya'da yapılan bir araştırmada (Mohiyeddini ve Montada, 1998) yüksek adil dünya inancına sahip kişilerin işsiz insanlara karşı daha az sempati duydukları, onları daha çok suçladıkları ve yardım etmeye daha az istekli oldukları bulunmuştur. Adil dünya inancını korumak için yardım etmenin mi yoksa kurbanı suçlamanın mı tercih edildiği sorusundan yola çıkan bir başka çalışmada da (Reichle, Schneider ve Montada, 1998) adil dünya inancının göçmenleri, işsizleri ve üçüncü dünya ülkelerindeki fakir insanları içinde bulundukları durumdan dolayı sorumlu tutma ile pozitif, onlara yardım etmeye gönüllülük ile negatif yönde ilişkili olduğu bulunmuştur. Avustralya'da yapılan bir çalışmada (Campbell, Carr ve MacLachlan, 2001) kişilerin adil dünya inancı arttıkça üçüncü dünya ülkelerindeki yoksulluğu bu insanların tembel olması, yetersiz olması, yeteneksiz olması, zeki olmaması gibi kişisel özelliklerle açılamayı tercih ettikleri görülmüştür. Benzer bir başka çalışmada da (Appelbaum, 2002) üniversite öğrencilerine, devletin ekonomik yardımlarına ihtiyacı olan insanların bu yardımı ne derece hak ettikleri sorulmuştur. Adil dünya inancı daha yüksek olanlar ihtiyaç sahiplerini içinde bulundukları 
durumdan dolayı daha çok sorumlu tutmuşlar ve bu yardımı daha az hak ettiklerini belirtmişlerdir.

İnsanların adil dünya inancı yükseldikçe akran zorbalığına maruz kalan kurbanları (Chapin ve Coleman, 2017; Poon ve Chen, 2015), aile içi şiddet kurbanlarını (Kristiansen ve Giulietti, 1990), cinsel taciz kurbanlarını (Adolfsson ve Strömwall, 2017; De Judicibus ve McCabe, 2001) ve tecavüz kurbanlarını (Strömwall, Alfredsson ve Landström, 2012; Yalçın ve Öztürk, 2018) daha çok suçladıklarını gösteren çok sayıda araştırma vardır. Örneğin, Adil dünya inancının kurbanı ve faili suçlama ile ilişkisinin araştırıldığ 1 bir çalışmada (Strömwall, Alfredsson ve Landström, 2012) adil dünya inancı yüksek kişilerin düşük kişilere kıyasla tecavüz kurbanını daha çok, faili ise daha az suçladıkları bulunmuştur. Benzer olarak, Kleinke ve Meyer (1990) tarafından yapılan bir çalışmada da, yüksek adil dünya inancına sahip kişiler düşük olanlara kıyasla bir tecavüzcü için daha kısa süre hapis cezası önermişlerdir. Türkiye'de yapılan bir çalışmada (Yalçın, 2006) da adil dünya inancının tecavüz kurbanlarına karşı önyargılı tutumları pozitif yönde yordadığı bulunmuştur. Adil dünya inancı yüksek kişilerin tecavüz mitlerini daha çok desteklediklerini (Hayes, Lorenz ve Bell, 2013; Vonderhaar ve Carmody, 2015; Russell ve Hand 2017) gösteren çalışmalar da, bu kişilerin tecavüz kurbanlarını suçlama potansiyeline daha çok sahip olduklarına işaret etmektedir.

Montada (1998) tarafından Almanya'da yapılan bir dizi çalışmada adil dünya inancı ve kurbanı suçlama arasındaki ilişki üçüncü dünya ülkelerindeki fakir insanlar, kanser hastaları, AİDS hastaları, trafik kazası kurbanları, tecavüz kurbanları gibi pek çok farklı kategoriden kurban için desteklenmiştir. Adil dünya inancı ve kurbanı suçlama ya da değersizleştirme konusunda yapılan çalışmalarda katılımcılar kurbanın kaderinden kişisel olarak etkilenmemiş, kurbanı kişisel olarak tanımamış, kurbanla yüzleşmemişlerdir ve olayın nedeni ya da sorumluluğun kimde olduğu konusunda ayrıntılı bilgiye sahip değillerdir. Kurbanları suçlamak için somut gerekçeleri yoktur. Tüm bu durumlarda adil dünya inancı devrededir. Güçlü bir adil dünya inancı, geniş sosyal ve politik haksızlıkların bulunduğu durumlarda gözlenen haksızlıkları görmezden gelme eğilimini artırmaktadır.

Kurbanı suçlamak ya da değersizleştirmek gerçekten adil dünya inancının tehdit edilmesi ile bir tür baş etme yolu mudur? Hafer (2000) 
daha önce söz edilen makalesinde yer alan ikinci çalışmasında bu soruya yanıt aramıştır. İlk çalışma ile aynı yöntemin kullanıldığı çalışmada katılımcılara Stroop görevinin yanı sıra kurbanın ne derece sorumluluk sahibi ve dikkatli bir insan olduğu da sorulmuştur. Adil dünya inancının tehdit edildiği koşulda adaletle ilgili kelimelere verilen tepki süresi uzadıkça kurbanı değersizleştirme artmıştır. Bir başka deyişle, adalet ile ilgili kelimelere en uzun sürede tepki verenler yani adil dünya inancı en çok tehdit edilenler bu inançlarını korumak için kurbanı daha çok suçlamışlardır. Hafer'in bulguları, kurbanların haksız yere yaşadığı acıların dünyanın adil olduğuna dair inancımızı tehdit ettiğini ve bu tehditle baş edebilmek için kurbanı değersizleştirdiğimizi göstermektedir.

Genel olarak araştırma bulguları adil dünya inancı kuramını destekler niteliktedir. Kurbanın uğradığı zararı tazmin etmek mümkün ise, yardım kolay ise, yardımın bedeli düşük ise, kişinin şansa ihtiyacı var ise insanlar adil dünya inancını korumak için kurbana yardım etmeye çalışmaktadır. Yardım etmek ya da zararı tazmin etmek mümkün değil ise, kurbanın kurban olma durumu devam ediyor ise, yardımın bedeli yüksek ise (ki bu göreli bir durumdur) insanlar kurbanı suçlayarak ya da değersizleştirerek, çektiği acıları hak ettiğini düşünerek psikolojik olarak adaleti yeniden inşa etmeye çalışmaktadır.

\section{Sonuç}

Adil dünya inancı kişinin kendini güvende hissetmesi, geleceğe yatırım yapabilmesi gibi birey açısından olumlu ve işlevsel bir inanç olabilir ama toplumsal sonuçları olumsuz görünmektedir. Ne yazık ki, adil dünya inancı bizi diğerlerinin şanssızlıklarına karşı katı ve duyarsız bir hale getirebilir. Bu inancı korumak için kurbanı suçlamak ya da değersizleştirmek kurbanların ikinci kez mağdur edilmesine neden olur. Kurbanlar, çektikleri acıların yanında bir de suçlanmanın, hor görülmenin, hatta damgalanmanın psikolojik sıkıntısını yaşamak durumunda kalırlar. Böyle durumlarda adaletsizlik katlanarak artar.

Kurbanları kaderlerini hak etmiş olarak algılama eğilimi sosyal adaletsizliklerin devam etmesine neden olabilir. Adil dünya inancı en az iki şekilde statükonun devamına katkı sunar. İlk olarak insanların adaletsizlikleri görmesini ve bunları düzeltmek için eyleme geçmesini engeller. 
Eğer dünya adil ise her şey olması gerektiği gibidir ve değişmesi gereken hiçbir şey yoktur. Statüko meşrudur. Öyleyse devam etmelidir. Oysa dünyanın şu anda adil olduğundan şüphe duyan insanlar gelecekte daha adil bir dünya umut edebilir ve bunun için çabalayabilirler. İkinci olarak, kurbanların yaşadıkları haksızlık için kendilerini suçlamalarına ya da diğerleri tarafından suçlanmamak için susmalarına yol açar. Bu sessizlik, sistemin yanlış yanlarının gün yüzüne çıkmamasına, faillerin yaptıklarının pekiştirilmesine ve yanlış davranışların devam etmesine neden olur. Böylece failler fail, kurbanlar kurban olmaya devam ederler. Tacizcileri, tecavüzcüleri değil taciz ve tecavüz kurbanlarını suçlamak, zorbaları değil şiddet görenleri suçlamak, hırsızı değil soyulanı suçlamak, sosyal adaletsizlikleri değil kadınları, yaşlıları, hastaları, fakirleri suçlamak gibi davranışlar toplumun çoğunluğu tarafından yapıldığında sosyal adaletsizlikler görülemez ve değiştirilemez.

Adil bir dünya umut etmek ve dünyanın daha adil bir yer olması için çaba sarf etmek adil dünya inancından çok farklıdır. Bir şeyin idealize edilmesi, hayal edilmesi ya da istenmesi o şeyin halihazırda var olduğuna inanmaktan farklıdır ve farklı sonuçlara yol açar. Dünyanın adil olduğuna inanmak ortada bir adaletsizliğin olduğunu reddetmeye, kurbana karşı olumsuz tutumlara, kurbanı suçlamaya ve statükoyu desteklemeye neden olurken dünyada adaletsizliklerin olduğunu kabul etmek adaletsizlikleri görebilmeye, kurbanla empati kurabilmeye, kurbana yardım etmeye, durumu düzeltmek için çaba harcamaya neden olabilmektedir. 


\title{
EXTENDED ABSTRACT
}

\section{Belief in a Just World and Its Social Consequences}

\author{
Serap Akgün \\ Mersin University
}

Justice is a main issue that has always been occupying the human mind. People always think, decide and judge the extent to which the events, that they experienced, witnessed or heard, are just. According to Lerner's just world theory people are motivated to believe that the world is a fair place in which people get what they deserve; good people are rewarded while bad people are punished. Believing that the world is a just place is a fundamental illusion, since individuals are motivated to maintain that belief, even when it is counterfactual. In fact life is not always fair; people have been victims or witnesses of injustices in everyday life but still they tend to believe that the world is a just place. This belief leads people to perceive the world as stable and controllable. People think that in this fair world that they live in, they will get what they deserve and they will not be innocent victims of unforeseeable events. Thus, individuals become more confident about their good-fortune and they can strive to reach their long-term goals. Due to this belief, people perceive the world as a safe place and protect their mental health (Lerner, 1980). The belief in a just world is quite functional in terms of predicting the future and feeling secure therefore people are resistant to give it up. If confronted with the evidence that the world is not a just place individuals might feel disturbed and uncomfortable (Lerner and Miller, 1978, s.1030).

In some cases we see that bad things happen to good people. In these situations, we cast doubt on the belief in a just world. Lerner (1980) suggests that innocent victims threaten the individuals' belief in a just world. Hafer (2000) tested this hypothesis using a modified Stroop task in an experimental study. Results indicated that color-identification response latencies were greater for justice-related words than for neutral words when the justice has not been served, but not when there was 
retribution. Witnessing an innocent victim suffering threatens the belief in a just world therefore justice related words capture attention and interfere with color identification task.

When individuals' just world belief is threatened they try to maintain and save it using rational or irrational strategies. Rational strategies include accepting injustice and then trying to restore the justice by adopting actions such as helping the victim or trying to compensate for his/her harm. Irrational strategies, however, consist of cognitive distortions such as denial of injustices, reinterpretation of cause of the event, blaming the innocent victim or derogating the character of the victim. Helping the victim is used to restore justice if helping or compensation is possible or the cost of helping is not too high (Lerner and Simon, 1966). Individuals tend to use irrational strategies such as blaming innocent victims for their fate if helping the victims is not possible or too costly. Rubin and Peplau (1973) proposed that people may differ in the extent to which they believe in a just world. Some people believe very strongly that the world is a just place while others recognize that the world is not always a just place. In order to measure individual differences in this belief the authors developed the Just World scale.

A number of studies (Bierhoff, Klein and Kramp, 1991; Zuckerman, 1975) investigating the relationship between just world belief and helping behavior found that individuals with a high belief in a just world helped more than did individuals with a low belief in a just world. Other studies (Mohiyeddini and Montada, 1998; Reichle, Schneider and Montada, 1998; Yıldırım and Akgün, 2013) however, have indicated that individuals with a low level of just world belief have tended to help more to the victims of social injustices compared to high just world believers.

As mentioned before, helping to the victim is not the only way to attempt to restore justice. Sometimes people may engage in a variety of defensive ways that help to maintain a sense of justice such as blaming victims for their misfortune. In a study by Reichle, Schneider and Montada (1998) it was found that belief in a just world is positively correlated with assigning responsibility to migrants, poor people in the third world countries, and unemployed individuals, whereas negatively correlated with willingness to help them. 
Recent studies has indicated that strong believers in a just world have a greater tendency to blame innocent victims of peer bullying (Chapin and Coleman, 2017; Poon and Chen, 2015) victims of domestic violence (Kristiansen and Giulietti, 1990) victims of sexual harassment and rape (Adolfsson and Strömwall, 2017; De Judicibus and McCabe, 2001; Strömwall, Alfredsson and Landström, 2012; Yalçın and Öztürk, 2018) compared to weak believers. In Germany, a series of study by Montada (1998) the relationship between just world belief and victim blaming was supported for poor in the third world, cancer patients, AIDS victims, accident victims, and rape victims.

Belief in a just world might be an adaptive and functional belief, however, its social consequences can be harmful for society as well as the victims. Perceiving the victims' misfortune as deserved leads to continue social injustices. Belief in a just world contributes to maintain the status quo, at least by two ways. First, it restrains people to see and strive to change injustices. If the world is a just place then everything as it should be, there is no need to change anything. The status quo is legitimate therefore it should be maintained. Second, just world belief leads innocent victims blame themselves for their fate or remain silent not to be blamed by others. This silence causes the wrongness of the system will not come to the light, reinforcing the perpetrators for their harmful behavior and continuing their misconducts. In this way the system will not change the perpetrators will continue to be perpetrators and the victims will continue to be victims.

\section{Kaynakça / References}

Adolfsson, K. ve Strömwall, L.A. (2017). Situational variables or beliefs? A multifaceted approach to understanding blame attributions. Psychology, Crime \& Law, 23(6), 527-552.

Appelbaum, L.D. (2002) Who deserves help? students' opinions about the deservingness of different groups living in Germany to receive aid. Social Justice Research, 15(3), 2001-225.

Bierhoff, H.W., Klein, R. ve Kramp, P. (1991). Evidence for the altruistic personality from data on accident research. Journal of Personality, 59(2), 263-280. 
Brewer, W. F. (1996). Good and bad story endings and story completeness" In (R. J. Kreuz and M. S. MacNealyeds.) Empirical Approaches to Literature and Aesthetics, (261-271) Norwood, NJ: Ablex.

Campbell D., Carr S. C. ve MacLachlan M. (2001). Attributing "third world" poverty in Australia and Malawi: a case of donor bias? Journal of Applied Social Psychology, 31, 409-430.

Chapin, J. ve Coleman, G. (2017). Children and adolescent victim blaming. Peace and Conflict: Journal of Peace Psychology, 23(4), 438-440.

De Judicibus, M. ve McCabe, M.P. (2001). Blaming the target of sexual harassment: impact of gender role, sexist attitudes, and work role. Sex Roles, 44, 401-417.

Dik, T. (2010) Atasözlerinde adil dünya inanc1. Milli Folklor, 22(88), 28-32.

Hafer, C.L. (2000). Do innocent victims threaten the belief in a just world? evidence from a modified stroop Task. Journal of Personality and Social Psychology, 79(2), 165-173.

Hayes, R.M., Lorenz, K., ve Bell, K. A. (2013). Victim blaming others: Rape myth acceptance and the just world belief. Feminist Criminology, 8(3), 202-220.

Jose, P.E. ve Brewer, W.F. (1984). Development of story liking: character identification, suspense, and outcome resolution. Developmental Psychology, 20(5), 911-924.

Jose, P. E., D'Anna, C.A. ve Krieg, D.B. (2005). Development of the comprehension and appreciation of fables. Genetic, Social, and General Psychology Monographs, 131(1), 5-37.

Kleinke, C.L. ve Meyer, C. (1990). Evaluation of rape victim by men and women with high and low belief in a just world. Psychology of Woman Quarterly, 14(3), 343-353.

Kristiansen, C., ve Giulietti, R. (1990). Perceptions of wife abuse: Effects of gender, attitudes toward women, and just-world beliefs among college students. Psychology of Women Quarterly, 14, 177-189.

Lerner, M. J. (1965). Evaluation of performances as a function of performer's reward and attractiveness. Journal of Personality and Social Psychology, 1, 355-360.

Lerner, M. J. (1975). The justice motive in social behavior:Introduction. Journal of Social Issues, 31, 1-20.

Lerner, M. J. (1980). The Belief In A Just World: A Fundamental Delusion. New York: Plenum Press. 
Lerner, M. J. (1998). The two forms of belief in a just world: Some thoughts on why and how people care about justice.In (L. Montada, M. Lerner ve J. Melvin Eds). Responses To Victimizations and Belief in a Just World, (s. 247-269). New York: Plenum Press.

Lerner, M. J. ve Miller, D. T. (1978). Just world research and the attribution process: Looking back and ahead. Psychological Bulletin, 85, 10301051.

Lerner, M. J. ve Simmons, C. H. (1966). Observer's reaction to the "innocent victim": Compassion or rejection? Journal of Personality and Social Psychology, 4, 203-210.

Mohiyeddini, C. ve Montada, L. (1998). BJW and self-efficacy in coping with observed victimization: results from a study about unemployment. In (L. Montada, M. Lerner ve J. Melvin Eds. Responses to Victimizations and Belief in a Just World, (s. 41-54). New York: Plenum Press.

Montada, L. (1998). Belief in a just world: A hybrid of justice motive and selfinterest? In (L. Montada, M. Lerner ve J. Melvin) Eds. Responses to Victimizations and Belief in a Just World, (sayfa 216-246). New York: Plenum Press.

Poon, K. ve Chen, Z. (2015). How does the source of rejection perceive innocent victims? The Journal of Social Psychology, 155, 515-526.

Reichle, B., Schneider, A. ve Montada, L. (1998). How do observers of victimization preserve their belief in a just world cognitively or actionally? Findings from a longitudinal study.In (L. Montada, M. Lerner ve J. Melvin Eds). Responses to Victimizations and Belief in a Just World, (s. 55-64). New York: Plenum Press.

Rubin, Z. ve Peplau, L. A. (1975). Who believes in a just world. Journal of Social Issues, 31(3), 65-90.

Rubin, Z. ve Peplau, L. A. (1973). Belief in a just world and reactions to another's lot: a study of participants in the national draft lottery. Journal of Social Issues, 29(4), 73-93.

Russell, K.J. ve Hand, C.J. (2017). Rape myth acceptance, victim blame attribution and just world beliefs: A rapid evidence assessment. Aggression and Violent Behavior, 37, 153-160.

Strömwall, L.A. Alfredsson, H. ve Landström, S. (2012). Blame attributions and rape: effects of beliefin a just world and relationship level. Legal and Criminological Psychology, 18, 254-261. 
Vonderhaar, R.L. ve Carmody, D.C. (2015). There are no "innocent victims": The influence of just world beliefs and prior victimization on rape myth acceptance. Journal of Interpersonal Violence, 30(10), 1615-1632.

Yalçın, M.A. ve Öztürk, E. (2018). Cinsel saldırı suçu mağduru kadınlara karşı toplumsal tutumlar ile adil dünya inancı ve çelişik duygulu cinsiyetçiliğin ilişkisi. Türkiye Klinikleri Journal of Forensic Medicine and Forensic Sciences, 15(2), 43-51.

Yalçın, Z.S. (2006). Effects of ambivalent sexism, locus of control, empathy, and belief in a just world on attitudes toward rape victims. Yayımlanmamış yüksek lisans tezi, Orta Doğu Teknik Üniversitesi, Ankara.

Yıldırım, N. ve Akgün, S. (2013). Sivil toplum kuruluşu gönüllülerinin sosyal sistemin meşruiyetine ilişkin algıları, adil dünya inançları ve sosyal baskınlık yönelimleri. Toplum ve Sosyal Hizmet, 24(1), 115-128.

Zuckerman, M. (1975). Belief in a just world and altruistic behavior. Journal of Personality and Social Psychology, 31(5), 972-976.

\section{Kaynakça Bilgisi / Citation Information}

Akgün, S. (2019). Adil dünya inanc1 ve toplumsal sonuçları. OPUSUluslararası Toplum Araştırmaları Dergisi, 14(20), 2227-2247. DOI: 10.26466/opus.610173 